\title{
The Best of the Gross Split in Oil and Gas Production Sharing According to Indonesian Law
}

\author{
Suherman ${ }^{1}$, Syafira G Rahayu ${ }^{2}$ \\ \{suherman_upn@yahoo.com ${ }^{1}$, syafirarahayu276@gmail.com² ${ }^{2}$. \\ Faculty of Law UPN Veteran Jakarta, Jakarta, Indonesia', Faculty of Law UPN Veteran Jakarta, Jakarta, \\ Indonesia $^{2}$
}

\begin{abstract}
The oil and natural gas sector is a vital natural resource controlled by the state as mandated in Article 33 paragraph 3 of the 1945 Constitution. Thus, the State as the holder of authority over oil and gas resources can provide power to the private sector or contractor for oil and gas management cooperation. Through the gross split of revenue sharing from oil and gas production, it is expected to benefit the country so that prosperity is achieved for all the people of Indonesia. This type of research is normative-empirical. The specific target to be achieved is to find out the best of the gross split in oil and gas production sharing in Indonesia.
\end{abstract}

Keywords: oil and gas regulation, revenue sharing, gross split.

\section{Introduction}

Based on the Regulation of the Minister of Energy and Mineral Resources / PERMEN ESDM No. 08 of 2017 Concerning Gross Split Production Sharing Contracts, since the stipulation of the ministerial regulation the production sharing contract for oil and gas cooperation between the government and investors uses a Gross Split production sharing contract, so that it no longer uses results with a cost recovery scheme. Gross Split is a scheme of sharing oil and gas production without returning operating costs. So, the Government from the beginning of the cooperation contract has determined the share of profits with investors or operating costs are the responsibility of the investor. Whereas the Cost Recovery scheme is profit sharing with the mechanism of returning operating costs, so after calculating how much operating costs have been incurred by investors, then after that the benefits of oil and gas cooperation will be shared between the Government and investors.

The Government, the Ministry of Energy and Mineral Resources (ESDM), through an interview Mr. Arifin Tasrif when interviewed by CNBC Indonesia said that he would consider setting policies that would allow investors to choose either the Gross Split scheme or the scheme for cost recovery results to be applied in cooperation with the Government [1]. In fact, if seen from the condition of the availability of oil and gas resources in Indonesia, the production results are currently decreasing, while the demand for oil and gas resources is increasing and varied, based on the annual report of the Special Task Force for Upstream Oil and Gas Business Activities (SKK Migas) period 2018, the prospect of Oil and Gas reserves is decreasing and is more in the East, especially in the deep sea, in other words Oil and Gas 
reserves will be difficult to find without sophisticated infrastructure and technology because they are in hard to reach areas [2].

Sophisticated infrastructure and high technology certainly require a lot of operating costs. Therefore, in this case the results sharing scheme applied must be able to accommodate such conditions so that it can run in accordance with the mandate of the Constitution of year 1945 Article 33 Paragraph 3 which is aimed at the prosperity of the people. Based on the background above, the problem in this journal is how the Government determines the sharing of oil and gas production through Gross Split in Indonesia.

\section{Research Methods}

In conducting this research the writer uses the normative-empirical legal research method [3]. The type of data used in this study is secondary data, which consists of primary legal materials, secondary legal materials and tertiary legal materials. This research also uses empirical research. Empirical legal research is a research method that uses empirical facts taken from the field in Ministry of energy and mineral resources of Republic Indonesia, both obtained from interviews and directs observations of brand matters. The three data collection thechniques in empirical legal research were used induvidually, separately, and together at the same time. The technique comprised interviews and questionaires. 


\section{Results And Discussion}

The government has made policies and provisions related to the economy that are used as a guide by the Government in carrying out the wheels of development in the country. These policies and provisions as a direction for a country's economic activities are called economic constitutions. The constitution must not conflict with the state constitution. State constitutions usually contain provisions regarding state control or ownership by the state. This is in accordance with the Indonesian Constitution which is regulated in Article 33 paragraph 3 of the Constitution of year 1945 namely that natural resources which in their control are in the hands of the State through the Government in their use must be intended for the greatest prosperity of the people.

The concept of control by the State of oil and gas natural resources is restated in Article 4 Paragraph 1 of Law Number 22 Year 2001 Concerning Oil and Gas, which states that oil and natural gas are strategic non-renewable natural resources contained in the territory Indonesian mining law is a National asset whose control is in the hands of the State [4] which in this case is held by the Government as the holder of mining authorization. The meaning of mastering here does not mean having but rather sovereignty to manage natural resources for the achievement of people's prosperity.

Law Number 22 Year 2001 Concerning Oil and Gas itself is a basic rule of oil and gas business activities which is divided into 2 (two) types of business activities namely upstream business activities and downstream business activities [5]. Upstream business activities are business activities that focus on oil and gas exploration and exploitation activities. Meanwhile, the basis for upstream Oil and Gas business activities is the Cooperation Contract (KKS) between the government as the holder of mining authority and the investor. Cooperation Contracts (KKS) are as a form of production sharing contracts or other cooperation contracts that are more beneficial to the State in upstream oil and gas business activities, the results of which are aimed at the prosperity of the people. (Article 1 number 19 of Law No. 22 of 2001). The form and system of contracts between the government and investors within the scope of Oil and Gas mining in Indonesia itself has been amended several times, starting with a concession system, then with the Contract of Work system, until now it is used as a Production Sharing Contract. The Revenue Sharing System in the profit sharing contract itself has been replaced by a system from the Cost Recovery system to the Gross Split system.

This cost recovery system is regulated in Government Regulation Number 79 Year 2010 Concerning Refundable Operating Costs and Income Tax Treatment in the Upstream Oil and Gas Business Sector, this system is implemented with a mechanism for returning operating costs in the form of oil and natural gas production results which are valued at costs incurred by the Contractor during the exploration and exploitation activities and activities related to the removal of oil and gas from the well to the surface [6], after all production and operating costs incurred by the contractor, then the profit between the Government and the contractor is divided. With the amount of profit sharing as follows: For Petroleum, 85\% for the Government and 15\% for the Contractor, while for Natural Gas, 70\% the Government and $30 \%$ the Contractor [7]. 
Distribution of production results with the percentage mentioned above is carried out on the remaining oil and gas yield or called ETBS (equity to be split) which has been reduced by FTP (First Tranche Petroleum) first as well as the operating and production costs of the Contractor [8]. FTP is the right of the parties to take and receive a portion of oil based on a certain percentage as agreed. FTP-I is the right of contractors and the government to extract and receive a portion of oil based on a certain percentage $(20 \%$ or $15 \%)$ and about $10 \%$ to $20 \%$ on FTP-II [9]. Which is SKK Migas's right or not shared with the Contractor.

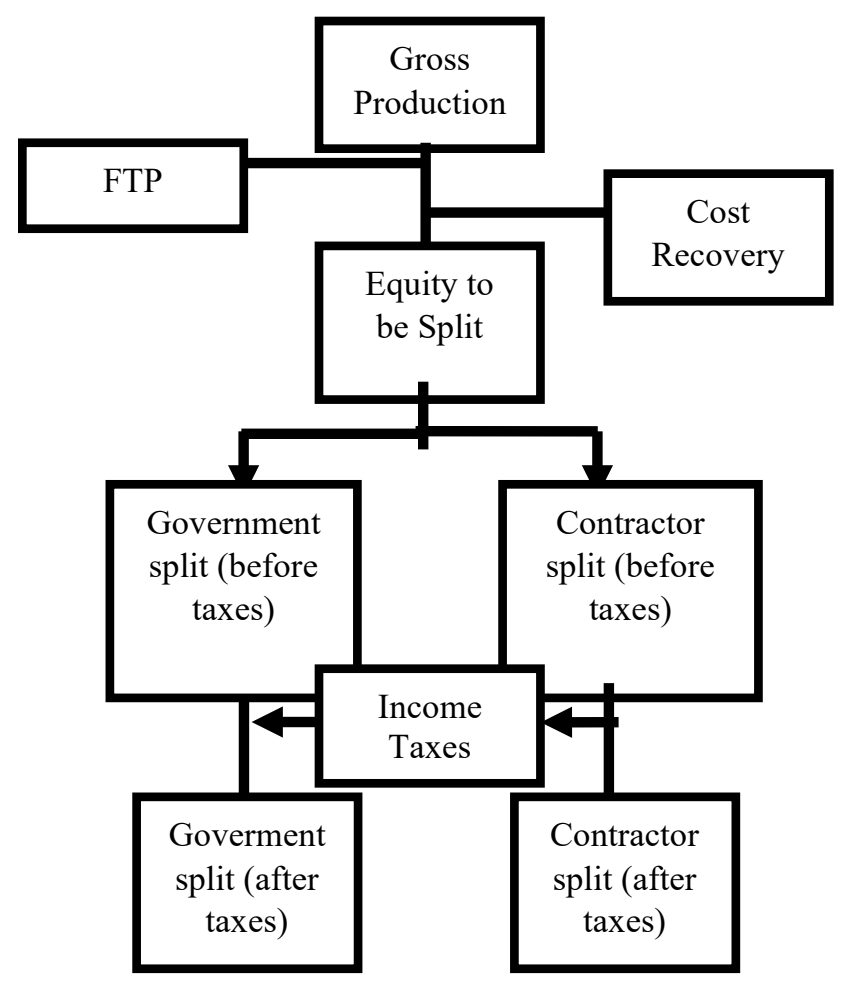

Figure. 1 Revenue sharing schemes cost recovery

Based on the above scheme, it can be seen that the amount of ETBS (equity to be split) which will be shared between the Contractor and the Government in calculating the profit sharing carried out between the Government and the Contractor each year is greatly influenced by operating costs. Where the greater the operating costs the smaller the ETBS (equity to be split) to be shared between the Contractor and the Government, thereby reducing the portion for the country. In connection with this, if seen from the problems that arise in the application of cost recovery before, cost recovery schemes are easy targets for cost recovery claim markup's by contractors, where the mark-up of cost recovery claims results in very high operating costs so that the government's portion becomes smaller. A common cause that can lead to cost recovery claims mark-ups is in the use of costs for oil and gas field operations with a cost recovery scheme that is applied in the production sharing, the contractor will tend not to think too much about the amount of operating costs it incurred and the effectiveness of its use because it will be returned by the Government later. In addition, sometimes the ability of SKK 
Migas knowledge and skills to prove the ineffectiveness of the use of operating funds by the contractor cannot detect this.

Based on the findings of the BPK-RI (Indonesian Supreme Audit Board), in the fiscal year 2004 and 2005, the BPK found that the total cost recovery mark-up claims that occurred totalled more than Rp.14.20 trillion [10], in 2007 the Supreme Audit Agency recorded, based on the results of examinations of 13 oil contractors, found a figure of Rp.39.9 trillion which should not have been paid as a cost recovery by the Government to the contractor and in 2016 based on the examination results recorded IDR. 2.56 trillion [11].

In 2017, the Government issued a new policy towards oil and gas revenue sharing cooperation, which initially with cost recovery became Gross Split. This, based on Article 1 Number 7 of the Regulation of the Minister of Energy and Mineral Resources Number 08 Year 2017 Concerning Gross Split Production Sharing Contracts, in the distribution of oil and gas production results with a gross split scheme carried out without a mechanism of returning operating costs, which in this case Operating costs are borne by the relevant non-Government contractor. In the gross split scheme, according to the standard split contract profit sharing system VI paragraph 6.1 concerning handling operating costs, operating costs incurred by the Contractor can be used as a component of income tax deduction [12].

In the gross split scheme, the percentage split between the Government and the Contractor based on Article 5 Paragraph (1) of the Regulation of the Minister of Energy and Mineral Resources Number 08 Year 2017 Regarding Gross Split Production Sharing Contracts, in essence is for oil $57 \%$ of the State and $43 \%$ of the share The contractor while for natural gas is $52 \%$ of the State portion and $48 \%$ of the Contractor's portion. This percentage, or what is referred to as base split, is based on Article 4 of the Regulation of the Minister of Energy and Mineral Resources No. 08 of 2017, depending on the components that can provide additional / reduced splits for contractors, namely variable and progressive components.

The variable component is related to the level of difficulty of field development, the split correction that will be added to the Contractor will be even greater if field development is more difficult, and vice versa. As field development becomes easier, split correction will be smaller. The parameters in the Component variable consist of working area status, field location, reservoir depth, availability of supporting infrastructure, type of reservoir, carbondioxide (CO2) content, hydogren-sulfide (H2S) content, petroleum density, TKDN (Component Level Domestic) during the field of development (Plan of Development) and production stages.

While the progressive component consists of the price of petroleum, the price of natural gas and the cumulative amount of oil production and natural gas, which when the selling price of production (the price of oil and natural gas) gets smaller, the split correction will be even greater and vice versa, when the selling price gets higher, the split correction will get smaller and when the amount of production is still small and capital is not yet again, the split correction will get bigger and as the cumulative production increases, the split correction will get smaller. So it can be seen that the calculation of the contractor's part is Base Split (Variable Component correction number + Progressive Component correction number).

In connection with that, as is known, in the oil and gas mining sector, the implementation of oil and gas business activities is guided by Article 33 paragraph 3 of the 1945 Constitution which states that in principle must be carried out based on two things namely "control" State "and" people's prosperity. Which means state control here means that the State has power in business activities that involve the utilization of oil and gas resources both as regulators and implementers of oil and gas mining business activities, which in carrying out their roles both 
as regulators and implementers of oil and gas mining business activities. it must be aimed at the maximum prosperity of the people so that it must benefit the State more. [13]

Based on interviews with Mr. Bobi Guntoro, S.H., M.H, Head of the Subdivision of the Directorate General of Oil and Gas, there are some of the best of the gross split system in oil and gas production sharing in Indonesia, as follow: [14].

a. Effective and Efficient

Profit sharing applied in oil and gas revenue sharing contracts must be effective and efficient. The effective and efficient aspect in this case can be seen from the time in determining the profit sharing and the percentage of profit sharing applied.

1) Time

Pursuant to Article 7 of Government Regulation No. 35/2004 concerning Oil and Gas Business Activities, Oil and Gas Business Activities, in the implementation of exploration and exploitation activities the maximum duration of implementation is only 30 years [15]. While the time to carry it out especially in this case exploration requires quite a long time that can reach 10 years. So in determining the distribution of initial production results on the submission and approval of the plan of development after it is discovered that the work area produces commercially valuable oil and gas must be relatively fast. In revenue sharing with a gross split scheme, the process of approval of production sharing in its plan of development is relatively fast, which is a maximum of a month because in this case all operating costs borne by the contractor so there are no problems in the approval of operating costs that will be used by the contractor in the development of the field of work. Also in the gross split scheme, the percentage that will be used as a component of addition or subtraction in the variable component and the progressive component of the correction value is clear, making it easier to determine the profit sharing between them.

Whereas in profit sharing with cost recovery schemes, the production sharing approval process in the plan of development is relatively long due to the determination of operating costs which often causes debate between the parties, namely SKK Migas and the PSC Contractors due to operating costs that are unlimited or not there are clear limits.

2) Use of Costs for Oil and Gas Field Operations

In profit sharing with a cost recovery scheme, the contractor will tend not to think too much about the amount of operating costs he incurred and the effectiveness of its use because all will be returned by the Government, whereas in a gross split scheme, where operating costs are borne by the Contractor, the contractor will certainly try to use the costs As minimum as possible, by suppressing cost effectively, the contractor has the opportunity to get greater results.

3) Percentage of Profit Sharing Amount Applied

The percentage of the final production share must be greater than the State's share of oil and gas production as the holder of authority for oil and gas mining. When viewed in this case, basically in its policy both the gross split system and the cost recovery scheme the percentage of the initial amount of profit sharing before being influenced by certain components is equally greater for the State, but in this case in terms of uncertainty in the amount of the results, for cost recovery scheme results with unlimited operating costs returned, as is known based on data from the Ministry of Energy and Resources, in the period of 2016 the value of cost recovery that must be returned by the Government to the Contractor is around $47.83 \%$ which if added to the contractor's part the percentage of the final share of the contractor's share will be more than the Government's.

\section{b. Flexibility}


Flexibility or flexibility in this case is flexibility in terms of field development (plan of development) relating to the costs to be used for field development operations (facilities and infrastructure as well as the technology to be used). In the production sharing with the Gross Split system, in determining the costs to be used for field development operations both to accommodate the facilities, infrastructure and technology to be used, the amount of the costs is left to the contractor or in accordance with the wishes of the contractor because in this case as is known by the contractor will bear all costs in the operation of the oil and gas field in its non-Government jurisdiction.

Whereas in profit sharing with the Cost Recovery system, in the process of determining the costs to be used for field development operations both to accommodate the facilities, infrastructure and technology to be used, the amount of the fee depends on the results of discussions between the contractor and SKK Migas, because as has been explained that in the profit sharing with a Cost Recovery system that will cover the operating costs of the oil and gas field is the Government. The problem that often occurs in this case is the debate over the technology issues that will be used because most contractors want a technology that is classified as sophisticated with a cost that is not insignificant which sometimes according to the results of SKK Migas research to manage the work area related does not require such technology [16].

\section{c. Risk Imposition}

The risks involved in carrying out oil and gas exploration are enormous. The success rate of finding commercially valuable oil and gas reserves in exploration activities is only around $20 \%$ to $30 \%$ with costs ranging from IDR. 27 billion to IDR. 92 billion only for field drilling on land with the total cost of conducting exploration activities is around US \$ 25 million to US $\$ 45$ million in this case if no oil and gas reserves are found, both in the cost recovery scheme and the gross split the risk is in the contractor but if it is found even though the amount or grade is not proportional to the operating costs used to find and obtain it and in this case what is used is a cost recovery scheme so the risk is clearly in the hands of the Government as the party that has to return the operating costs incurred by the contractor.

\section{d. Attracting Investor's Interest}

Investors or Contractors who in this case are business entities or permanent establishments with unlimited funds ownership play an important role in the operation of oil and gas businesses because oil and gas business activities certainly require insufficient capital and adequate technology. So the production sharing system adopted in the oil and gas production sharing contract must be able to attract investors.

Former Deputy Minister of Energy and Mineral Resources, Arcandra Tahar through an interview with detik.com stated that the factors sought and considered by investors to collaborate in the oil and gas mining sector are certainty, efficiency and simplicity [17].

1) Certainty

When viewed in terms of certainty or certainty in the distribution of oil and gas production results, the profit sharing with the Gross Split system is more certain than the Cost Recovery system. Because, as explained earlier, in a revenue sharing system with a Gross Split system there are clear provisions accompanied by exact figures in determining the components that will affect the correction of the addition or reduction of the contractor's part in the percentage of profit sharing, so that the size of the contractor and the government is clearer and certainly. While in the Cost Recovery system, the amount of operating costs that must be returned by the government in the form of oil and gas production obtained from the reduction of the government's share in the production sharing with contractors is uncertain, because as it is 
known that the amount of operating costs is unlimited which is the result of a long debate between the contractor and SKK Migas.

\section{2) Efficiency}

When viewed in terms of efficiency, especially in terms of time efficiency, as explained earlier, in the Gross Split system of revenue sharing, the approval process for production results in the plan of development is relatively fast, which is at most a month when compared to the Cost Recovery system in the determination and approval takes a long time.

3) Simplicity

In determining the cost recovery system revenue sharing as it is known there is often debate in determining the operating costs to be returned by the Government to the Contractor so that the process is more complicated when compared to the Gross Split profit sharing system which is a production sharing system without a mechanism for returning operating costs by the government so that the determination of operating costs is certainly more practical or straightforward because there will be no debate between the contractor and SKK Migas in this case.

\section{Conclusion}

Oil and gas production sharing (MIGAS) in Indonesia through gross split means Gross Split is a scheme of sharing oil and gas production without returning operating costs. Thus, the Government from the beginning of the cooperation contract has determined the share of profits with the contractor or operating costs are the responsibility of the contractor after the distribution of profits. There are several aspects that can be of investor interest in the Gross Split scheme, namely effective and efficient aspects, flexibility and risk loading. The effectiveness and efficiency aspects can be seen from the time in determining the profit sharing, the use of costs for oil and gas field operations and the percentage of profit sharing amount applied. The flexibility aspect is seen based on the determination of the amount of costs for operating the oil and gas field. While the risk loading aspect is seen as more risk in the hands of the Government or the Contractor.

\section{References}

[1] CNBC Indonesia, "Kontrak Gross Split Migas Bakal Tidak Wajib," 2019. https://www.cnbcindonesia.com/news/20191128104519-8-118601/kontrak-gross-split-migasbakal-tidak-wajib.

[2] SKKMIGAS, "Laporan Tahunan SKK 2019. https://www.skkmigas.go.id/publikasi/annual-report.

[3] J. Ibrahim, Teori \& Metodologi Penelitian Hukum Normatif. Bayumedia, 2006.

[4] Indonesia, Undang-Undang Tentang Minyak dan Gas Bumi, UU No. 22 Tahun 2001, LN No.136 Tahun 2001, TLN Nomor 4152, Pasal 4 Ayat 1. Indonesia, 2001.

[5] Salim H.S, Hukum Pertambangan Di Indonesia, V. Jakarta: Rajawali Pers, 2010.

[6] B. Lubiantara, Ekonomi Migas Tinjauan Aspek Komersial Kontrak Migas. Jakarta: Gramedia, 2012.

[7] Republik Indonesia, Peraturan Pemerintah Tentang Biaya Operasi yang Dapat Dikembalikan dan Perlakuan Pajak Penghasilan di Bidang Kegiatan Usaha Hulu Minyak dan Gas Bumi, PP No.79 Tahun 2010, LN. 2010 No. 139, TLN No. 5173, Pasal 7. 2010. 
[8] A. Sutedi, Hukum Pertambangan, III. Jakrta: Sinar Grafika, 2012.

[9] Rudi M. Simamora, Hukum Minyak dan Gas Bumi. Jakarta: Djambatan, 2000.

[10] A. Sutedi, Hukum Pertambangan, III. Jakarta: Sinar Grafika, 2012.

[11] nasional.kontan.co.id, "BPK temukan mark up cost recovery 2016 Rp 2,5T," 2019. https://nasional.kontan.co.id/news/bpk-temukan-mark-up-cost-recovery-2016-rp-25-t.

[12] Standar Kontrak Bagi Hasil Gross Split, VI.

[13] A. Madjedi Hasan, Kontrak Minyak dan Gas Bumi Berasas Keadilan dan Kepastian Hukum, I. Fikahati Aneska, 2009.

[14] "Wawancara dengan Bobied Guntoro, Kepala Sub Bagian Penyusunan Peraturan PerundangUndangan Kementerian Energi dan Sumber Daya Mineral Direktorat Jenderal Minyak dan Gas Bumi," 2019.

[15] Republik Indonesia, Peraturan Pemerintah Tentang Kegiatan Usaha Hulu Migas, PP No. 35 Tahun 2004, LN. 2004 No. 123, TLN No.4435. 2004.

[16] A. Rinto Pudyantoro, A to Z Bisnis Hulu Migas, II. Jakarta: Petromindo, 2013.

[17] finance.detik.com, "Arcandra Pamer Keberhasilan Skema Bagi Hasil Gross Split," 14 Desember 2019, pukul 22:48 wib, 2019. https://finance.detik.com/energi/d-4434512/arcandra-pamerkeberhasilan-skema-bagi-hasil-gross-split. 